\title{
An empirical examination of the factors influencing consumer's purchase intention toward online shopping
}

\author{
Muhammad Dharma Tuah Putra Nasution \\ Yossie Rossanty \\ Universitas Pembangunan Panca Budi - Medan \\ North Sumatra, Indonesia \\ Ku Halim Ku Ariffin \\ Nurliyana Izzati Binti Mohd Zaini \\ School of Business Innovation and Technopreneurship \\ Universiti Malaysia Perlis (UniMAP), Malaysia
}

\begin{abstract}
Keywords
Price, Ease of Use, Usefulness, Purchase Intention, Online Shopping.
\end{abstract}

\begin{abstract}
Online shopping is overgrowing around the globe. Consumers unite and combine their purchasing power in order to bargain for a significant volume discount from a seller. On the other hand, it also helps the new seller to enter the competitive markets easily. The objective of this study is to examine the relationships among the factors and to assess how it influences consumers' purchase intention on online shopping. The main problem that online retailer faced nowadays is how to attract the consumer's purchase intention toward online shopping especially among the student because we know that most student does not have fixed income. So it will prevent them from spending more on online shopping. In order to make a business successful, some good strategy needs to be implemented, and the retailer does not only need to acquire the new customers but also need to retain the existing customers. Purchase intention as the possibility of purchasing a special brand in a product category during purchase. There were 200 sets of the questionnaire had been distributed randomly among the PPIPT students. The present study used descriptive statistics, regression, and Pearson correlation. In short, price, ease of use and usefulness can only explain $(R$ Square $=0.973)$ variation of factors influencing consumers' purchase intention towards online shopping. Durbin-Watson considers the accepted range of 1.486 shows there was no autocorrelation problem with data. The condition index $=77.598, V I F=1-10$, and tolerance fell $=0.1-10$ within the accepted range. F-value is found to be a significant level (Sig. $F=0.000)$. The regression model used in this study is adequate, the model is fit. As a conclusion, a lack of confidence and trust in utilizing the Internet as a shopping channel. The ethnic group also dominated by Malay only which could be a source of bias.
\end{abstract}

Corresponding author: Muhammad Dharma Tuah Putra Nasution

Email addresses for the corresponding author:dharma_nasution@dosen.pancabudi.ac.id

First submission received: $18^{\text {th }}$ July 2018

Revised submission received: $27^{\text {th }}$ November 2018

Accepted: 10 $0^{\text {th }}$ December 2018

\section{Introduction}

Online shopping is apart of electronic commerce in which consumers can direct to purchase the goods or services from the seller over the internet. Online shopping allows consumers to purchase faster, more alternatives and easy to order products or services with comparative and lowest price (Cuneyt \& Gautam, 2004). E-bay is one of the successful online retailing corporations in the world. It is an online shopping website that allows people and business to purchase or sell their products broadly. In overall, online shopping has two specific processes, which are B2B (Business-to-Business) and B2C (Business-toConsumer). In $\mathrm{B} 2 \mathrm{~B}$ requires the retailer to purchase the products from other business and sell it out in their products and sell it out to the customers.

The emergence of the internet has created opportunities for firms to stay competitive by providing customers with a convenient, faster and cheaper way to make purchases. JARING was the first to 
introduce internet service in Malaysia back in 1990 (Harn el at., 2006). The report by International Data Corporation (2005) indicated that the future of online shopping in Malaysia is bright and promising. The government of Malaysia introduced business e-commerce in early 1998 (Kamarohim, 2003). Electronic commerce has become an opportunity due to the marketer has some basis to deliver product and services with internet market channel. It is more effective and profitable for marketers that can serve their customers if they concern and understand their customers need and want.

Online shopping is designed to provide convenience to customers. Online shopping will make customers more efficient, and enhance satisfaction. For instance, customers will ease to access the product's information. Also, online shopping will save the customer's time, effort and money. In business, customer's satisfaction is an essential element to make the business success and gain high profit. In customer's perceptions, online shopping has its pros and cons. The saving time is the main advantages of online shopping. Customers need to visit the online shop's websites and find any product to fulfill their need and want. All of the financial transaction through online banking, it makes customers easier and saves their time compared to the traditional purchasing method that required the customer's visit to the retail outlet. Besides that, as compared with the retail outlets, online shopping websites provide unlimited space for the retailer to upload the images and information about their products. Other than that, many of the products that are selling online are much cheaper than products that selling in shops or malls. It is due to the products that purchase through online do not include any additional fees. So, customers can enjoy the purchasing process of products easily and low cost.

However, one of the disadvantages of online shopping is the safety of customer's personal information. Criminals can steal private information such as name, mobile number, credit card, and account bank number. It is the most worrying things for customers who were using online shopping. Besides, the time consuming is also one of the reasons for customers who do not prefer online shopping. This case is because when customers purchase the products online, they expect to receive their items as fast as possible. However, in online shopping, it needs a few days for the products to deliver to the customers.

Furthermore, products that sell through online cannot be touch by the customers, and they can see the images of the products. Thus, this may cause the customers do not satisfy when the products that they receive is low quality or not the same as what they are expected. All of these issues may influence the customer's purchase intention toward online shopping.

According to IBIS World Research, it forecasts that there will be $8.6 \%$ increment of online revenue per year in the year in the next five years. Even though online shopping had growth rapidly nowadays, consumers still not confident toward the security of the website that required people giving their personal information to the online retailer.

The objective of this study is to examine the relationships among the factors and to assess how it influences consumers' participation and purchasing intention for online shopping in Malaysia context. According to antecedent studies, although the price is the key factor that consumers concerned the most. However, other factors way consumers' purchasing intention, such as attitudes, reference group and others (Chang, Lai, \& Wu, 2010). Further, limited studies are being done on consumers' purchasing intention on group purchasing websites, especially in Malaysia context. Due to the online shopping concept still in the initial stage of development, Therefore, it is necessary to investigate the factors affecting consumers' purchase intention in this area.

The main problem that online retailer faced nowadays is how to attract the consumer's purchase intention toward online shopping especially among the student. The reason is mostly student does not have fixed income, and the situation will prevent them from spending more on online shopping. In order to reach a business successful, the retailers do not only need to acquire new customers but also need to retain the existing customers. From some researches that had been conducted previously, most of the customers are more prefer to purchase in the retail store rather than online shopping.

Besides that, the significant problems that online retailer faced nowadays are how to improve their services and activities to stimulate the customer's purchase intention. For many researchers that had been conducted previously, most of the consumers also choose to purchase in the retail store more than 
through online. Around $70 \%$ of the customers also think that the security of the website is a significant factor that caused them to do not prefer online shopping.

Even though there have many researchers had found out the factors that affecting purchase intention towards online shopping, but there has seldom research that examines specifically in several reasons such as price, ease of use, and usefulness for online shopping. Also, there have seldom research had to do their researches that focus in Perlis. In order to improve the purchase online and change the negative impressions about online shopping, it should focus more on several factors that affect the consumer's purchase intention to understand more the probability of each factor had influenced the consumer's purchase intention. However, some factors can lead to negative feedback meanwhile several factors can lead to positive feedback. Thus, this study is done to find out which factors among the several factors related to the consumer's purchase intention towards online shopping.

This study attempts to answer the following research questions:

- Does price have a significant effect on consumers' purchase intention toward online shopping?

- Does ease of use have a significant effect on consumers' purchase intention toward online shopping?

- Does usefulness have significant effects on consumers' purchase intention toward online shopping?

\section{Literature Review}

\section{Introduction on Purchase Intention}

One of the primary concepts in marketing literature is purchase intention which has routine applications in researches and also covers a wide range of products and services. Kim and Kim (2004) define purchase intention as the tendency of consumers with the identified aim where it is usually measured concerning real purchasing. Moreover, Crosno, Freling \& Skinner (2009) expressed that purchase intention refers to the possibility of purchasing a particular brand in a product category during purchase. However, the implementation of the product's purchase intention depends on various factors such as customer willingness and interest to the product, imposed social pressure on the customer from others and a general sense of what is received. These factors could be pursued according to the theory of reasoned action (TRA) and product evaluation model (PEM). TRA is proposed by Fishbein and Ajzen (1975) and is widely used in the consumer behavior literature and purchase intention studies (Botha \& Atkins, 2005; Beadnell, Baker, Gillmore, Morrison, Huang \& Stielstra, 2008; Alsughayir \& Albarq, 2013).

Thus, online purchase intention refers to the willingness of customers to adopt Internet to make an actual purchase or comparing offering price by different online retailers (Iqbal, Rahman, and Hunjra, 2012). According to Pavlou (2003), online purchase intention can be explained as the situation when an individual is willing and intends to engage in an online transaction.

Online purchase intention refers to the strength of the consumer's plan to carry out a particular purchasing behavior over the Internet (Salisbury, Pearson, Pearson, and Miller, 2001). It could also be defined as the desire of consumers to make an actual purchase through the online retail shops (El-Ansary and Roushdy, 2013). According to Poddar, Donthu, and Wei (2009), online purchase intention can be used to predict the actual purchase behavior. It refers to an outcome of consumers 'evaluation of the quality of a website, availability of information and products.

Apart from that, Sam and Tahir (2009) mentioned online purchase intention is the possibility that the consumer will purchase the product. Furthermore, Monsuwe, Dellaert, and Ruyter (2004) stated that consumers'online purchase intention is associated with their prior purchase experiences and it will directly impact their online shopping behavior. Meanwhile, Internet shopping history might lead to a direct and indirect influence on consumers'online purchase intentions (Kim, Lee, and Kim, 2004). Moreover, Shim and Drake (1990), as cited in Leeraphong and Mardjo (2013), stated that great online purchase intention usually results from customers who already have past purchase experiences which can help them to reduce uncertainties.

Besides, Theory of Planned Behaviors suggested that an individual's actual behavior is determined by whether the individual has the intention to perform. Moreover, Zwass (1998), as cited in Kwek, Tan, Keoy, and Pazdil (2011) also proposed that online purchase intention as the consumer's desires to build a 
business relationship and have business transactions with the online retailers. In this research, online purchase intention can be defined as the state of affairs that an individual is willing and intend to engage in the online transaction (Pavlou, 2003).

\section{Introduction to Online Shopping}

Online shopping is known as internet shopping or electronic shopping. It defined as the process of shopping where consumers purchase products or services from any vendors and sellers through online (Mastercard Worldwide Insight, 2008). Online shopping also can be defined as search, observation and browse the internet for purchasing any products or services (Kim, 2004). Besides that, online shopping is defined as a way that time saving and a convenient way to purchase a product, but most also express discomfort about sending personal or credit card information over the internet (John Horrigan, 2008).

Nowadays, the internet had become a favorite way which serves to make a settlement in daily life such as electrical bill payment, credit card payment, insurance payment, searching for information and purchasing products. Thus, the action of purchase products through the internet is considered in online shopping. The University of Carolina, Los Angeles (UCLA) communication policy (2001) defined that online shopping is the third most popular activities on the internet after email using and web browsing. The world biggest online shoppers are British and German. The most popular items that are purchased through the internet are shoes, clothing, airline ticket, books, video games and other electronic products (ACNielsen Report on Global Consumer Attitudes towards Online Shopping, 2007).

However, online shopping is still new, and customers are less familiar and often more skeptical about online shopping in Malaysia (Haque and Khalibi, 2007). According to Rajkumar (2001), he stated that online shopping had taken a stronghold in western countries and will continue to experience growth, but yet in Malaysia is still lag far behind compared to western countries. This case is because Malaysia is preferred to purchase something only after they see and touch the products. Since online shopping had to start to grow in Malaysia, it is essential for the retailer to build a relationship with customers and reach the maximum level of purchase intention and customer satisfaction. The retailer must make sure that customers have a good image and good shopping experiences through online shopping.

Moreover, online shopping and online sales are important manifestations that the internet is used as a platform tool for business ( $\mathrm{Li}$ Zhao, 2010). Most of the business will be held online to gain the maximum profit with the minimum costs as the internet had widely used by population nowadays. It is considered the most effective and cheaper ways to help a business to promote and sell the products. One of the primary challenges that faced by the online retailer is how to attract the customers and motivate them to shift from the traditional shopping to online shopping (Belhan et al., 1999).

According to the research that had been conducted by John Paynter and Jackie Lim (2001). In the state that the growth of the internet in Malaysia can be considered as slow. The committing a transaction online in Malaysia was not as popular as Western, even though there has some previous research that had proven that online shopping had continuous growth. However, there only has a small number of Malaysian are using online shopping.

According to the research that had been conducted by Thailand Development Research Institute, ecommerce had covered the global market which includes e-commerce in United State had captured around $70 \%$ of the world market value, Europe had captured around $14 \%$ of market value, and Canada had captured around $8 \%$ of the market value. On the other hand, Asia Pacific just only had capture 5\% of the market value (E-revolution, 2000).

\section{Purchase Intention towards Online Shopping}

Purchase intention is defined as consumers' willingness to purchase certain products or services from the online group purchasing website (Ailawadi, Neslin, \& Gedenk, 2001). Online purchase intention refers to the consumers' willingness to be involved in an online transaction (Pavlou, 2003). Purchase intention has been broadly used as a focal construct to indicate consumers' purchasing behavior in market research (Yang \& Mao, 2014).

Past studies indicated that ease of use and usefulness influence consumers' purchasing intention on e-commerce websites (Gefen et al., 2003; Ha \& Stoel, 2008). However, Shergill and Chen (2005) argued in their findings that information privacy is consumers' primary concern online shopping. 
According to Chang and Wildt (1994), the authors identified two attributes used to estimate the consumers' purchasing intention. They are purchasers' willingness to purchase and purchasers' willingness to repurchase from an e-commerce website soon. This case is in line with the previous finding (Pavlou \& Gefen, 2004) in which they indicated that purchasing intention positively ways consumers' actual purchase behavior. Moreover, it may affect purchasers' to repurchase intention from the websites.

\section{Advantages and Disadvantages of Online Shopping}

According to Webcheck (2000), it defined that there have two most prominent advantages of online shopping that are saving time and it is a convenient purchasing method and easy to purchase. Customers who prefer online shopping will be more save time and energy when they purchase the products without directly visiting the shop. The consumer can purchase in anywhere and anytime, even though sitting at home. For consumers, it is a convenient purchasing method and easy to purchase anything. Besides that, consumers do not need to go to many places to purchase the different types of products at the same time. This case is because all types of products are also available online. Consumers can purchase multiple items at the same time. Also, online shopping also provides the opportunity for consumers to leave their feedback and share their views with others.

Though online shopping, consumers can saving their time by avoiding to go through several procedures such as waiting, dressing up, traveling, parking, dressing up and carrying (Salste, 1996). For a consumer, time is a significant predictor of online shopping (B. Foucault, 2002). Consumers who have little discretionary time especially those needs work in long hours and have the limit time to purchase products in traditional store (B. Fourcault, 2002). This case is because online shopping is operating in 24 hours a day and seven days a week, it allows the consumers to purchase their desired products or services anytime and anywhere. As a result, online shopping has views of the time saving than the traditional modes of shopping (Alrek and Settle, 2002).

Besides that, according to Marry De Swatdt (2008), it stated that one of the advantages of the internet was the consumers can easily to access an abundance of free information. As compared with the traditional way that requires more energy and time to search, the internet is considered as the most effective and easy way to search the information for any products or services without any charges or fees. According to the study that had conducted by ACNielsen Research, it had come out several reasons that why the consumers purchase products through online shopping. The table below will show the reasons why consumers prefer online shopping.

Table 1 Reason of Consumer Shop Online

\begin{tabular}{|l|l|}
\hline Reasons & Percent (\%) \\
\hline Conveniences/Save times & 78 \\
\hline Better Price & 51 \\
\hline Easier Shopping & 40 \\
\hline More Selection & 43 \\
\hline Ability to find a move personalized gift & 28 \\
\hline More information available about the products & 20 \\
\hline Others & 8 \\
\hline
\end{tabular}

Sources: McGann, "Online Holiday Purchase to Grow Despite Growing Security Concern", AC Nielsen Research, November 30th, 2004.

Based on the table above, convenient is the most prominent factor that motives consumers to shop online. This case is because online shopping is more superior compared to traditional shopping in term of location, purchasing procedure and timing (Hanson, 1999). The 24 hours of every day available to the consumers in any location had brought a huge convenience to the consumers to purchase their desired products or service.

The second factor that attracts consumers purchase online is the competitive prices that offered by the online retailers. Normally, consumers who prefer online shopping is pursuing low-cost products and services that are cheaper than the traditional shopping. The main reasons that help the online retailer to offer their products at low cost are due to the shrinking cost of the information processing, low operating 
cost and contribution of the Internet (Rowley, 2000). Besides, there also have another reason that causes the online retailer to offer their products at low cost especially for the new online retailer is due to the competitive pressure. Usually, a new online retailer will use the low-cost strategy as the primary weapon to compete with other competitors (Hanson, 1999).

Besides that, the third factor that due to the great selection and broader availability of the products choice that offers in online shopping. There has no limit on physical space on the number of products that allow the online retailer to display their products. Thus, online retailers can provide a wide range of products in their online storefront compared to the traditional shops (Adeline Chua, 2006).

Easy to gather product information is one of the factors that motives customers prefer to choose online shopping. According to Rowley (2000), it mentioned that the internet had allowed the consumers to be more effective and efficiency in searching the product information. This case had made the purchasing process more simple compared to traditional shopping.

However, the main disadvantages of online shopping are the consumers would not have the chance to try, feels and touching the products before they purchase it. (North et al., 2003). Basically, consumers who prefer online shopping can purchase the items based on the image and information provided by the retailer such as the prices, colors, sizes, and some information details. It cannot ensure that the consumer can receive the products that they expect due to the effect of the product image. Thus, customer satisfaction will be decreased.

According to the research conducted by North et al. (2003), they have come out some reasons why customers do not prefer online shopping. The table below will show the reason and percentages of total participants who cite each reason:

Table 2 Reasons of Consumers do not prefer online shopping

\begin{tabular}{|l|l|c|}
\hline $\begin{array}{c}\text { Reason Of Customer do not Prefer Online } \\
\text { Shopping }\end{array}$ & \multicolumn{2}{c|}{$\begin{array}{c}\text { Percentages of Total Participants Who } \\
\text { Cite Each Reason }\end{array}$} \\
\hline Gender & Male (\%) & Female (\%) \\
\hline Security Concern & 70 & 33 \\
\hline Unfamiliar Merchants & 41 & 54 \\
\hline Lack of Touch & 45 & 26 \\
\hline Too Difficult & 21 & 37 \\
\hline
\end{tabular}

Based on the table above, it had clearly stated that the main reasons that consumers do not prefer online shopping is because of the security concern. There has $70 \%$ male, and $73 \%$ of female consumers are not confident about the security of online shopping. This case is because all the transaction will be held online. Moreover, there may have many parties involved in the transaction process such as ISPs, products comparison site, search engine, payment providers and delivery companies (Office of Fair Trading, 2007). This case will make the consumers lack confidence in the security of online shopping. Besides that, it also shows that one of the main reasons for not purchase online is lack of touch. Other reasons were included the unfamiliar merchants, and it was too complicated for them to use online shopping facilities. The consumers need to develop internet skills if they decide to purchase online (Office of Fair Trading, 2007). It was brought difficulties to the consumers who are not familiar with using the computer to purchase online.

\section{Factors Influencing Consumers' Purchase Intention Price}

Price is the main reason for motivating customers to purchase (Kotler \& Keller, 2006). Price sensitivity refers to consumers who are sensitive to price and respond to change the prices for particular products and services (Wakefield \& Inman, 2003; Pi et al., 2011). Price consciousness refers to consumers who pay attention only to products or services at lower prices because they want to avoid paying higher prices for the same products or services (Sinha \& Batra, 1999).

Pricing is the most effective method to stimulate price-sensitive consumers to obtain the greatest value for their money or to purchase a particular product at the lowest price possible (Brassington \& 
Pettitt, 2006). Price sensitive by consumers will notice and respond based on the changes in the prices published in group purchasing websites (Pi et al., 2011).

The previous study indicated that there are two major types of price system commonly used in online group purchasing website (Erdogmus \& Cicek, 2011). The first type is recognized based on dynamic pricing mechanisms. It implies that a huge group of purchasers unite to perform collective purchasing, with significant discounts on price, through the group purchasing website. The sellers predefined the discount prices and the number of purchasers. Each purchaser in a group will enjoy a similar discount if they can form a group within a given period. The second types refer to the grouppurchasing vendors offer particular products at bigger discounts, usually more than $50 \%$, but the price does not reduce any further even if the number of purchasers increases.

\section{Ease of Use}

Davis (1989) defined Ease of Use as "the degree to which an individual believes in using a particular system would be free of effort." It influences the individual's behavioral intention to conduct the financial transaction on a website (Yang \& Mao, 2014). Contrarily, Koufaris and Hampton-Sosa (2004) explained Perceived Ease of Use as consumers' subjective perception, which is regards to the extent of effort required to learn and use the particular website. The work of Selamat, Jaaf, and Ong (2009) explained that consumers prefer a more user-friendly and simple system for online shopping. This case is supported by Teo (2001) in the study that consumers are likely to use the particular technology if the system appeared as easy to use and require less effort to learn.

Previous studies indicated that website characteristics play an important role to determine Perceived Ease of Use in online purchase activities (Zeithaml, Parasuraman, \& Malhotra, 2002; Beldona, Morrison, \& O'Leary, 2005). Further, the study of Lim and Ting (2014) demonstrated that Perceived Usefulness and Perceived Ease of Use form a basic measurement towards consumers' acceptance of a particular new website (Lim \& Ting, 2014). Several components need to be taken into consideration, such as simple process flow, flexible and easy to teach (Rahman et al., 2013). Nevertheless, effective product searching and easy checkout process are two important features that will help to improve Perceived Ease of Use and achieve higher consumer's purchase intention (Yang \& Mao, 2014).

\section{Usefulness}

Davis (1989) defined usefulness as "the degree to which an individual believes in using a particular system would enhance his or her performance." Henderson and Divett (2003) indicate that consumers recognize the application as useful if the application can perform tasks effectively. According to Gefen, Karahanna, and Straub (2003), Usefulness was used to measure shopper's subjective valuation of the utility which is recommended by the current updated information technology in an explicit task-related context.

According to the study by Pikkarainen, Pikkarainen, Karjaluoto, and Phanila (2004) in the study of TAM acceptance online banking, they found that Usefulness positively affects the actual behavior of Internet banking adoption. Sanchez-Franco and Roldan (2005) indicated in their study that Usefulness and behavioral intention were correlated and it was strong among goal-directed users.

Usefulness has a positive effect on consumer attitude. If the benefit of online shopping is highly perceived, attitude towards online shopping will be positive as well. The time was saving, and convenience offered by online shopping has seen it become increasingly attractive with penetration of the Internet in modern times. It reduces the costs which otherwise would have been incurred in searching for the goods, offers a price cheaper than brick-and-mortar stores and is perceived continuously as secure (Foley \& Sutton, 1998).

Several studies have been done on the influence of perceived usefulness on online purchase intentions. For instance, Renny, Guritno and Siringoringo (2013) while studying perceived usefulness, ease of use and attitude towards online airline ticket purchase measured perceived usefulness using five indicators. These were- being fast (quick), time-saving, effort saving, cost reducing, and overall usefulness. The findings showed that the most significant contributor among them in building perceived usefulness was the overall usefulness of online transaction, whereas the least was its use in effort saving. These findings implied that respondents believed that purchasing airlines ticket online provided 
effectiveness, better performance, and productivity which are equivalent to perceived usefulness of TAM (Triandis, 1980).

Another study by Heijden, Verhagen, and Creemers (2003) carried out a study on understanding online purchase intentions by looking at the contributions from technology and trust perspectives. The result suggests that perceived risk and perceived ease-of-use are antecedents of attitude towards online purchasing. The effect of perceived risk was strongly negative in both cases, and the effect of perceived ease-of-use was positive in one case. The data did not support a positive effect from trust in the online store and the perceived usefulness of the website. As opposed to the study by Renny, Guritno, and Siringoringo (2013) who found 12 usefulness to be positively related with online purchase intentions, this study data did not support a positive effect from trust in the online store and the perceived usefulness of the website. This case raises inconclusive discussion on the role of perceived usefulness on online shopping intentions. This case is one of the justifications to conduct this study.

\section{Estimates for the Future in Malaysia}

According to the survey of Taylor Nelson Sofres (2000), it mentioned that online shopping had become a significant component in the purchasing decision in Malaysia. Based on the finding of the survey, there have more and more Malaysia had started preferring online shopping compared to a few years ago. Malaysia had a huge potential for growth in internet procurement. However, Malaysia may hard to adopt online shopping due to the cultural inertia (John Paynter and Jackie Lim, 2001). The reason is Malaysian are prefer to shop in the retail store than to purchase via the online shop. Besides that, this culture will be change if the consumer had aware of the advantages of online shopping. The potential of online shopping would become higher if the consumer in Malaysia believed that online shopping is safe and reliable.

\section{Research Methodology \\ Research Framework}

According to the Margaret Eisenhart (1991) has identified that there have three types of a framework which are a theoretical framework, practical framework, and conceptual framework. A theoretical framework is the research framework that guides the research activities by relying on formal theory. At this process, the specific research question will determine according to the theory that had been chosen. After that, the data will be gathered, and the finding is needed to support the related theory.

A practical framework is not the same like theoretical framework. This framework does not rely on formal theory but is relying on the accumulated practice knowledge of practitioners and administrators. According to the Seriven (1986), research questions of this framework are from the knowledge base, and the research finding is to support the practice.

Lastly, a conceptual framework is similar to a theoretical framework. It is based on the previous research, but the conceptual framework may build from both current and possible wide range of the sources. Besides, a conceptual framework can be defined as a set of board ideas and theories help the researchers will use the conceptual framework to clarify the research questions and aim.

\section{Theoretical Framework}

Based on the literature review, the theoretical framework purposed in the following:

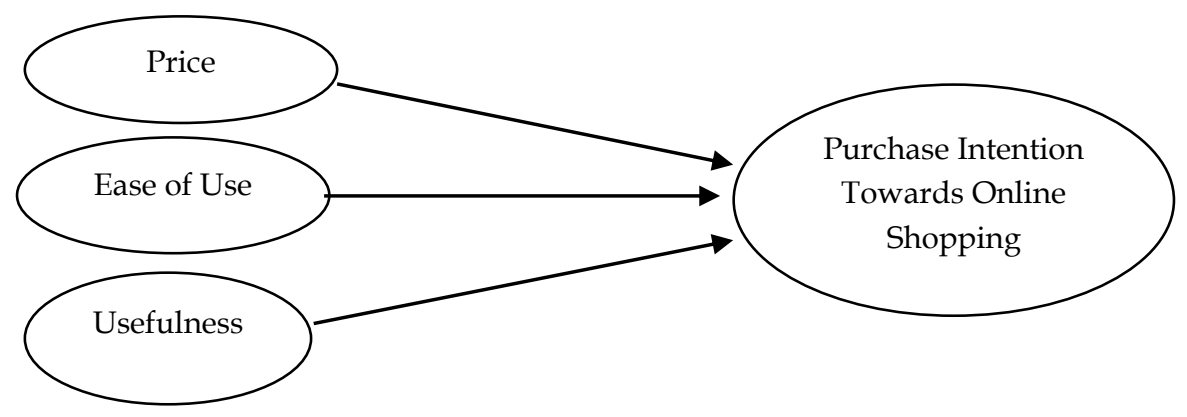

Figure 1 Theoretical Framework of this research 
The hypothesis is a formal statement that presents the expected relationship between the independent variable and the dependent variable (Creswell, 1994). It is a simple prediction of the study. A hypothesis should be developing before the research is conducted. Thus, it may allow identifying the research objectives and the relationship between the problems statement and literature review (Shalini Prasad, 2001). Therefore, there have several hypotheses had been conducted as below:

H1: There is a significant positive relationship between price and purchase intention

$\mathrm{H} 2$ : There is a significant positive relationship between ease of use and purchase intention

H3: There is a significant positive relationship between usefulness and purchase intention

\section{Research Design}

Research Design is encompassed about the sample population, sampling, and data collection methods. It included the method to collect data and information. In this research, it also included the survey method. Besides that, stratified random sampling will be implemented in this research. Stratified random sampling means that population will be divided into subgroups before sampling. The percentages of an element in each group will be different in the population.

\section{Sample population}

In order to get reliable data and achieve the objectives of the research, there were 200 sets of the questionnaire had been distributed randomly among the UNIMAP students especially the PPIPT students. There have 200 respondents had been chosen to represent. All respondents will be chosen randomly from the first, second and third years students in business school.

\section{Sampling Method}

In this research, the respondent will be selected randomly in PPIPT students. The respondent will be randomly selected from different races, ages, and courses. In order to obtain a reliable result, there are 200 questionnaires were distributed randomly. Besides that, the questionnaire will be distributed to those consumers who are using online shopping.

\section{Data Collection Method}

There have many methods to collect data which depend on each research. Each of the collection methods had their advantages and disadvantaged. In this research, it had two type of sources of data, which is the primary and secondary data. The primary method is the method that data and information is collected directly from the area being a survey. In this research, the primary data is collected from the questionnaire, public survey, and the internet. Also, the questionnaires were distributed to the UNIMAP students especially PPIPT students who are preferred online shopping. Secondary data refer to the data that are collected from the journal, article, website, literature and the previous researches. It is the most cost saving and time-saving method to collect the information. Secondary data must be proven, trust and trusted. The secondary data in this research include the website, journal, and articles which about this research data.

\section{Questionnaire}

The questionnaire of this study was using languages which are English and Malay. The purpose of using two different languages is to help respondents to understand the questions easily. Furthermore, all respondents will be asked the same questions in the questionnaire.

\section{Results}

\section{Overview of Data Gathered}

Overall 300 questionnaires were distributed to the selected respondents, International Business and Engineering students in PPIPT. As a result, only 200 were successfully collected and used for analysis in the present research. Consequently, which made up $68 \%$ of the total questionnaires distributed were satisfactorily completed and tested by using the Statistical Package for the Social Science (SPSS) software version 22. Table 3 presents the sample profile of the questionnaire survey. 


\section{Demographic Profile}

Table 3 Summary of Demographic Profile

\begin{tabular}{|c|c|c|c|}
\hline Variables & Categories & Frequency & Percentage (\%) \\
\hline Gender & $\begin{array}{l}\text { Male } \\
\text { Female }\end{array}$ & $\begin{array}{l}110 \\
90\end{array}$ & $\begin{array}{l}55.0 \\
45.0\end{array}$ \\
\hline Age & $\begin{array}{l}18-22 \\
23-26 \\
27-30 \\
\end{array}$ & $\begin{array}{l}143 \\
45 \\
12 \\
\end{array}$ & $\begin{array}{l}71.5 \\
22.5 \\
6.0 \\
\end{array}$ \\
\hline Race & $\begin{array}{l}\text { Malay } \\
\text { Chinese } \\
\text { Indian } \\
\text { Others }\end{array}$ & $\begin{array}{l}150 \\
30 \\
16 \\
4\end{array}$ & $\begin{array}{l}75.0 \\
15.0 \\
8.0 \\
2.0 \\
\end{array}$ \\
\hline Course & $\begin{array}{l}\text { International } \\
\text { Business } \\
\text { Engineering }\end{array}$ & $\begin{array}{l}130 \\
70\end{array}$ & $\begin{array}{l}65.0 \\
35.0\end{array}$ \\
\hline Education & $\begin{array}{c}\text { Degree } \\
\text { Diploma }\end{array}$ & $\begin{array}{l}160 \\
40\end{array}$ & $\begin{array}{l}80.0 \\
20.0\end{array}$ \\
\hline
\end{tabular}

\section{Reliability Test}

Cronbach's coefficients alpha values for all factors that ranged from 0.703 to 0.843 indicated good inter-item consistency for each factor. Sekaran (1992) explained that testing establishes the reliability of a measure for consistency and stability of data collected.

Table 4 Results of Reliability Test

\begin{tabular}{|l|c|c|c|c|}
\hline Variables & $\begin{array}{c}\text { Number of } \\
\text { Items }\end{array}$ & $\begin{array}{c}\text { Items } \\
\text { Dropped }\end{array}$ & $\begin{array}{c}\text { Items } \\
\text { Recoded }\end{array}$ & Cronbach's Alpha \\
\hline Purchase Intention & 4 & - & - & 0.876 \\
\hline Price & 5 & - & - & 0.877 \\
\hline Ease of use & 6 & - & - & 0.880 \\
\hline Usefulness & 6 & - & - & 0.887 \\
\hline
\end{tabular}

As a result, the consistency of data shows the degree an item is independently measured of a concept. The reliability analysis was used to measure the goodness of data. For this reason, it is to ensure that all items used in each variable are free from error, hence providing consistent results. According to Sekaran (2003), alpha over 0.80 is considered good, whereas a range of 0.70 is considered acceptable.

\section{Descriptive Analysis of All Variables}

Table 5 Descriptive Analysis for present means and standard deviation

\begin{tabular}{|l|l|c|}
\hline Factors & Mean & Standard deviation \\
\hline Purchase Intention & 3.9738 & 0.93789 \\
\hline Price & 3.9560 & 0.92691 \\
\hline Ease of Use & 3.9875 & 0.86529 \\
\hline Usefulness & 3.9375 & 0.91033 \\
\hline
\end{tabular}

The result indicates that mean for all variables ranges between 3.9375 and 3.9875. Means and Standard deviation of independent variables measures which are price, ease of use and usefulness were $3.9560,3.9875$, and 3.9375 respectively whereas for the dependent variable, purchase intention barrier have a mean of 3.9738 and standard deviation 0.93789 . 
Table 6 Result of correlation, sig. (2-tailed), and $\mathrm{N}$ for all the study variables

\begin{tabular}{|c|c|c|c|c|c|}
\hline \multicolumn{6}{|c|}{ Correlations } \\
\hline & & AVEPI & AVEP & AVEE & AVEU \\
\hline \multirow[t]{3}{*}{ AVEPI } & Pearson Correlation & 1 & $.381^{*}$ & $.370^{*}$ & $.397^{*}$ \\
\hline & Sig.(2-tailed) & & 000 & 000 & 000 \\
\hline & $\mathrm{N}$ & 120 & 120 & 120 & 120 \\
\hline \multirow[t]{3}{*}{ AVEP } & Pearson Correlation & $.381^{*}$ & 1 & $.908^{*}$ & $.592^{*}$ \\
\hline & Sig. (2-tailed) & .000 & & .000 & .000 \\
\hline & $\mathrm{N}$ & 120 & 120 & 120 & 120 \\
\hline \multirow[t]{3}{*}{ AVEE } & Pearson Correlation & $.370^{*}$ & $.908^{*}$ & 1 & $.607^{*}$ \\
\hline & Sig. (2-tailed) & .000 & .000 & & .000 \\
\hline & $\mathrm{N}$ & 120 & 120 & 120 & 120 \\
\hline \multirow[t]{3}{*}{ AVEU } & Pearson Correlation & $.397^{*}$ & $.592^{*}$ & $.607^{*}$ & 1 \\
\hline & Sig. (2-tailed) & .000 & .000 & .000 & \\
\hline & $\mathrm{N}$ & 120 & 120 & 120 & 120 \\
\hline
\end{tabular}

Factors Influencing Consumers' Purchase Intention towards Online Shopping

In support of the study, multiple regression analysis was used to determine the factors influencing consumers' purchase intention towards online shopping. Table 7 presents the result of regression analysis on factors influencing consumers' purchase intention towards online shopping.

Table 7 Results of Regression Analysis

\begin{tabular}{|llll|}
\hline Variables & Beta & t-Ratio & Sig. t \\
\hline Price & 1.384 & 19.143 & 0.000 \\
\hline Ease of use & 1.101 & 31.962 & 0.000 \\
\hline Usefulness & -1.519 & -19.363 & 0.000 \\
\hline R square $=0.973$ & & & \\
Durbin-Watson $=1.486$ & & & \\
$\mathrm{~F}=2316.427$ & & & \\
Sig. F $=0.000$ & & & \\
Condition Index $=77.598$ & & & \\
\hline
\end{tabular}

Based on the regression analysis done to determine the factors influencing consumers' purchase intention towards online shopping, the price was found to have a significant effect (sig. $t=0.000$ ). This finding shows that price has accepted the factor for influencing consumers' purchase intention towards online shopping but other factors itself. The hypothesis H1, stating that there is a significant relationship between prices on the factors influencing consumers' purchase intention towards online shopping was supported.

The regression analysis also indicates that Ease of use has significant factors influencing consumers' purchase intention toward online shopping with (sig. $t=0.000$ ). Thus, $\mathrm{H}_{2}$ which stated there is a significant relationship between Ease of use on factors influencing consumers' purchase intention towards online shopping was substantiated.

At the same time, usefulness structure was found to have a significant effect with (sig. $t=0.000$ ). Hence, H3 which stated that there is a significant relationship between usefulness on factors influencing consumers' purchase intention towards online shopping, was substantiated.

In short, price, ease of use and usefulness can only explain 97.2\% ( $R$ Square $=0.972$ ) variation of factors influencing consumers' purchase intention towards online shopping. Durbin-Watson fell within 
the accepted range of 1.486 shows there was not autocorrelation problem with data. The condition index, VIF, and tolerance fell within the accepted range (Condition index $=77.598, \mathrm{VIF}=1-10$, tolerance $=0.1-10$ ). F-value is found to be significant at a one \% significance level (Sig. F $=0.000$ ). It concludes that the regression model used in this study is adequate or in other words, the model is fit.

\section{Discussion}

In this section, the researcher firstly presents the accepted hypotheses and will be followed by the rejected hypotheses. Hypothesis 1 examined the relationship between prices factors influencing consumers' purchase intention toward online shopping and this hypothesis was accepted. The findings indicate that price has a significant influence on consumers' purchase intention toward online shopping with Beta of (1.384), t-Ratio (19.143) and Sig.t (0.000). The price was found to have a significant effect (sig. $t$ $=0.000)$. The result is consistent with the findings from Yang and Mao (2014) and Kauffman and Wang (2001), both indicated that price has significant control over consumers' purchasing intention for online shopping. Yang and Mao (2014) found out that consumers had an impression of online shopping as a channel for getting a great discount and promotion.

Further, the finding also indicates that consumers tend to compare group volumes among various online shopping website before they decide to place their order. Similarly, the study by Fan, Chiang, Wang and Eric Wang (2010) explain that expensive products or luxury goods are not suitable to put on sale on the online shopping website because online shopping consumers are very price-sensitive consumers. This case implies price has strong influences on consumers' purchase intention and consumers see the Online shopping website as a channel to obtain products and services at the relatively discount price. Besides, consumers are sensitive to the prices, and they would compare the prices with other Online shopping websites, to obtain even lower prices, before they make a purchase. Also, as a student, they want to purchase products or goods within the lower price.

Hypothesis 2 was accepted because regression analysis showed that there is a significant relationship between ease of use on the factor for influencing consumers' purchase intention towards online shopping. This hypothesis posited that ease of use and consumers' purchase intention show a positive relation. The findings indicate that ease of use has a significant influence on consumers' purchase intention towards online shopping with Beta of (1.101), t-Ratio (31.962) and Sig.t (0.000) Therefore, the H2 is supported. The result implies that consumers in Malaysia can adapt to the online shopping websites business model easily as well as the rapidly changing online shopping platform. It also indicates that consumers in Malaysia are more technologically savvy and they are experienced in online shopping.

Moreover, it could be due to the majority of the respondents are cultivated, and they are capable navigate through the online shopping website without further guidance from others. Referring to the descriptive results presented in Appendix B, the majority of them hold at least a college diploma for their education level. Moreover, the age group of the respondents may sway the results as well. The majority of the respondents are aged from 18 to 22 years old, which translates that $71.5 \%$ of the overall population of the respondents. These respondents can adapt to new technology easier than other respondents, and online shopping is not something new to them. Contrarily, the present findings may indicate that online shopping website is simple and easy to use compared to the e-commerce website. Thus, consumers who have experienced in online shopping may able to navigate through the website easily.

Hypothesis 3 was accepted because regression analysis showed that there is a significant relationship between usefulness on the factor for influencing consumers' purchase intention towards online shopping. The findings indicate that usefulness has a significant influence on consumers' purchase intention toward online shopping with Beta of (-1.519), t-Ratio (-19.363) and Sig.t (0.000). Therefore, the H3 is supported and great significant influence on consumers' purchase intention towards online shopping. The result is consistent with the findings of Lim and Ting (2014) and Tsai et al. (2011).

Usefulness has significantly affected consumers' purchase intention when they found that online shopping enhances their purchase effectiveness. Besides, according to a study by Yoon (2015), Usefulness had statistically affected consumers' behavioral intention to purchase online. It implies that consumers are more likely to participate in group purchasing activities when they perceived the website is beneficial and useful. Other similar studies conducted by Rahman et al. (2013 concluded in their study that the effectiveness of online shopping can be sustained by improving the customers' usefulness in Malaysia. 
While some previous studies (Lu, Hsu, \& Hsu, 2005; Hassanein \& Head, 2004) supported the finding and indicates that usefulness has a positive impact on attitude towards online shopping. Hence, the last research objective is achieved, and the $\mathrm{H} 3$ is supported.

\section{Implications of the Findings}

The results of this study indicate that the three significant factors such as usefulness, price, and ease of use, demonstrated a relatively strong impact on consumers' purchase intention towards online shopping. On Usefulness, it implies that consumers are preferable to purchase products or services from the online shopping website if they perceived is useful, and they can obtain a great deal from online shopping website. Besides, online shopping websites can boost sale, encourage more consumers to participate, by improving the perceived usefulness of the website. A study by Rahman et al. (2013), on Malaysian consumers' participation in online shopping, indicated the same result as well.

With regards to price, it is the key factor that influences consumers to participate in online shopping websites. Consumers participate in an online shopping activity with the purpose to obtain remarkable deals, with significant discount rate and vendor used price to attract consumers to purchase their products or services. Further, consumers have an impression of online shopping as a channel to obtain a great discount and promotion (Yang \& Mao, 2014). Consumers would compare prices among various online shopping vendors before they place their order.

Last by not least, the ease of use in this study indicates that consumers pay less attention to the website characteristics, the design of a website and the system flow. Consumers willing to learn how to use the online shopping website while they perceived the website could help them to achieve what they need and want.

\section{Recommendations}

In support of the results of this study and theoretical consideration, some potential future research opportunities can be considered. With the advent of technology, consumers can provide reviews or comments from various devices which they own on almost every e-commerce websites, blogs, and grouppurchasing sites. Further with the growth of social networking and smartphone users, consumers are now easier to express their comments on the Internet. Thus, there is a need for marketers to understand how the Ease of use might influence consumers' purchase intention. Additionally, e-commerce websites which are built with easy to navigate user interface and user-friendly layout may improve consumers' trust towards the company (Koufaris \& Hampton-Sosa, 2004).

Therefore, this study aims to provide valuable information and insights to companies and researchers in this area. Firms which are aiming to venture into online purchasing may use this paper as a guide for improvement while companies that are already running online shopping businesses may find this paper useful as a benchmark to improve the grey areas.

\section{Limitations of the Study}

Online shopping is a new business model which bonds the traditional purchasing activities with the e-commerce store. It is still in the initial stage of development. Therefore, it has limited studies on consumers' purchase intention on online shopping websites. Further, many people and student are confused the traditional e-commerce website with the online group purchasing.

The sample size employed in this research is relatively small. Greater sample size will help to generate a more appropriate output and more precise findings. Further, the sampling location should be higher among student. Respondents from various states may have various points of view or perspective towards online shopping.

Consumers' satisfaction does not include in this research study. It is an important area to examine the consumers' willingness to purchase products or services from online shopping. With regards to that, it may help investigate consumers' repurchase intention as well.

Prices proved it has a positive correlation with consumers' purchase intention in online shopping of this study. Price is an important factor in any online transaction because consumers had an impression as a channel for getting a great discount and promotion. Online shopping websites and merchants need to ensure the collected information is secure and do not leak to the public. 
Also, this research only emphases on the online shopping website. With the advent of mobile technology nowadays, many e-commerce websites allow consumers to their mobile application. It is important to examine whether consumers prefer to visit the online shopping website through their mobile phone or their personal computer.

\section{Suggestions for Future Research}

With the advent of technology, consumers can provide reviews or comments from various devices which they own on almost every e-commerce websites, blogs, and group-purchasing sites. Further with the growth of social networking and smartphone users, consumers are now easier to express their comments on the Internet. Thus, there is a need for marketers to understand how the Ease of use might influence consumers' purchase intention.

Further, the factors that Ease of use needs to be managed properly as it consists of the comments from informants and recommenders (Lin et al., 2013). The information could be strategical as a communication channel and firms can make use of this useful information for their corporate strategy. Additionally, corporate website and blog will help to build relationships with their customers by providing factual information and encourage consumers to contribute their knowledge and comments (Selnes \& Sallis, 2003). Providing real-time feedback or promptly response to consumers' problems can help to build customer loyalty, thus generating sales (Senecal \& Nantel, 2004).

Therefore, this study aims to provide valuable information and insights to companies and researchers in this area. Firms which are aiming to venture into online purchasing may use this paper as a guide for improvement while companies that are already running online shopping businesses may find this paper useful as a benchmark to improve the grey areas.

\section{Conclusion}

The present study focuses on the factors influencing consumers' purchase intention towards online shopping. The discussion of the major findings concluded that all hypotheses were supported and positive relationship. Ease of use on consumers' purchase intention was found to have a significant impact in this study. While this study implies that it might due to consumers and students are technologically savvy and experienced in online shopping platform. Thus, they do not require further guidance from others. It also implies that Malaysian consumers are adapted to a new technological platform such as the online shopping website, which is still at the initial stage of development.

This research highlighted that Usefulness have a strong influence on customers' purchase intention. On Usefulness, it implies that consumers are preferable to purchase products or services from online shopping website if they perceived is useful, and they can obtain a great deal from the online shopping website. Besides, online shopping websites can boost sales, encourage more consumers to participate, by simply improving the perceived usefulness of the website. This study by Rahman et al. (2013), on Malaysian consumers' participation in online shopping, indicated the same result as well.

With regards to price, it is the key factor that influences consumers to participate in online websites. Consumers participate in an online shopping activity with the purpose to obtain remarkable deals, with significant discount rate and vendor used price to attract consumers to purchase their products or services. Further, consumers have an impression of online shopping as a channel to obtain a great discount and promotion (Yang \& Mao, 2014). Consumers would compare prices among various online shopping vendors before they place their order

There are several limitations found in this study. First, the online shopping business model is still in the initial stage of development. Thus, there are limited studies and findings to references. Second, consumer satisfaction was not included in the research study. It is an interesting area to study. It is an important area to examine the consumers' willingness to purchase products from online shopping. Thirdly, the ethnic group also dominated by Malay only which could be a source of bias. Lastly, the simple size is rather small and possible bias by answering the questions in favor of the researcher. The size of a population in PPIPT also high which is 1606 but respondent of the questionnaire is only 200 students. 


\section{References}

Ailawadi, K. L., Neslin, S. A., \& Gedenk, K. (2001). Pursuing the value-conscious consumer: store brands versus national brand promotions. Journal of marketing, 65(1), 71-89.

Alreck, P. L., \& Settle, R. B. (2002). The hurried consumer: Time-saving perceptions of Internet and catalogue shopping. Journal of Database Marketing \& Customer Strategy Management, 10(1), 25-35.

Alsughayir, A., \& Albarq, A. N. (2013). Examining a theory of reasoned action (TRA) in internet banking using SEM among Saudi consumer. International Journal of Marketing Practices, 1(1), 16-30.

Brassington, F., \& Pettitt, S. (2006). Principles of marketing. Pearson Education.

Chang, M. L., Lai, M., \& Wu, W. Y. (2010). The influences of shopping motivation on adolescent online-shopping perceptions. African Journal of Business Management, 4(13), 2728-2742.

Crosno, J. L., Freling, T. H., \& Skinner, S. J. (2009). Does brand social power mean market might? Exploring the influence of brand social power on brand evaluations. Psychology \& marketing, 26(2), 91-121.

Davis, F. D. (1989). "Perceived Usefulness, perceived ease of use, and user acceptance of information technology." MIS Quarterly, Vol. 13 No.3, pp. 319-340

Davis, F. D. (1989). Perceived usefulness, perceived ease of use, and user acceptance of information technology. MIS quarterly, 319-340.

El-Ansary, O., \& Roushdy, A. S. (2013). Factors Affecting Egyptian Consumers' Intentions for Accepting Online Shopping. The Journal of American Academy of Business, 19(1), 191-201. Erdogmus, I., \& Cicek, M. (2011). Online Group Purchasing: What is There for the Consumers? Procedia Social and Behavioral Science, 24, 308316.

Foley, P. \& Sutton, D. (1998). Boom time for electronic commerce-rhetoric or reality. Business Horizons, pp. 21-30.

Gefen, D., Karahanna, E., \& Straub, D. W. (2003). Trust and TAM in Online Shopping: An Integrated Model. MIS Quarterly, 27(1), 51-90.

Ha, S., \& Stoel, L. (2008). Consumer e-Shopping Acceptance: Antecedents in a Technology Acceptance Model. Journal of Business Research, 62(5), 565-571

Haque, Ahasanul and Khatibi, Ali, (2006). The Study of the Behaviour of Malaysian Consumers Towards Online Shopping. Asian Journal of Information Technology, 5: 12-19

Harn, A.C.P., Khatibi, A. and Ismail, H. (2006) "E-Commerce: A Study on Online Shopping in Malaysia." Journal Social Science, Vol. 13 No. 3, pp. 231-242.

Heijden, H., Verhagen, T. V., \& Creemers, M. (2003). Understanding online purchase intentions: Contributions from technology and trust perspectives. European Journal of Information Systems, 12(1), 41-48.

Iqbal, S., Rahman, K., \& Hunjra, A. I. (2012). Consumer Intention to Shop Online: B2C E-Commerce in Developing Countries. Middle-East Journal of Scientific Research, 12(4), 424-432.

Kamarohim, N.A.B. (2003), "Factors influencing the purchased of products or services through the internet," Available at:http://etd.uum.edu.my

Kim, E., \& Kim, Y. (2004). Predicting Online Purchase Intentions for Clothing Products. European Journal of Marketing, 38(7), 833-897.

Kotler P. \& Armstrong G. (2010), "Principles of Marketing," New Jersey: Pearson Prentice Hall.

Kotler, P., \& Keller, K.(2006). Marketing Management (12ed.). Upper Saddle River, New Jersey: Pearson Education Inc

Koufaris, M., \& Hampton-Sosa, W. (2004). The Development of Initial Trust in an Online Company by New Customers. Information and Management, 41, 377-397

Koyuncu, C., \& Bhattacharya, G. (2004). The impacts of quickness, price, payment risk, and delivery issues on on-line shopping. The Journal of Socioeconomics, 33(2), 241-251.

Kwek, C. L., Dazmin, D., Tan, H. P., Keoy, K. H., \& Pazdil, H. (2011). Perceived Risk, Perceived Technology, Online Trust for the Online Purchase Intention in Malaysia. International Journal of Business and Management, 6(6), 169-182.

Leeraphong, A., \& Mardjo, A. (2013). Trust and Risk in Purchase Intention through Online Social Network: A Focus Group Study of Facebook in Thailand. Journal of Economics, Business, and Management, 1(4), 314- 318

Levy, M. \& Weitz, B. (2012), Retailing Management, New York: McGraw-Hill.

Lim, W. M., \& Ting, D. H. (2014). Consumer Acceptance and Continuance of Online Group Purchasing. Journal of Computer Information Systems, 87-96.

Mastercard Worldwide Insights (2008).Online shopping in Asia-Pacific - patterns, trends and future growth. Retrieved from http://www.mastercard.com/

Monsuwe, T. P. Y., Dellaert, B. G. C., \& Ruyter, K. D. (2004). What drives consumers to shop online? A literature review. International Journal of Service Industry Management, 15(1), 102-121.

Pavlou, P. (2003). Consumer Acceptance of Electronic Commerce: Integrating Trust and Risk with the Technology Acceptance Model. IJEC, 7(3), 197-226. 
Pavlou, P., \& Gefen, D. (2004). Building Effective Online Market Places with Institution-based Trust. Information Systems Research, 15(1), 37-59.

Pi, S.-M., Liao, H.-L., Liu, S.-H., \& Lee, I.-S. (2011). Factors Influencing the Behavior of Online Group Purchasing in Taiwan. African Journal of Business Management, 5(16), 7120-7129.

Poddar, A., Donthu, N., \& Wei, Y. (2009).Web Site Customer Orientations, Web Site Quality, and Purchase Intentions: The Role of Web Site Personality. Journal of Business Research, 62, 441-450.

Rahman, M., Khan, A., \& Islam, N. (2013). An Empirical Study on Revealing the Factors Influencing Online Shopping Intention Among Malaysian Consumers'. Journal of HSSR, 1(1), 9-18.

Rajkumar, T.M. (2001), "E-procurement business and technical issues," Information Systems Management, Vol. 18 No. 4 , pp. 52-61

Renny, Guritno, S., \& Siringoringo, H. (2013). Perceived Usefulness, Ease of Use, and Attitude Towards Online Shopping Usefulness Towards Online Airlines Ticket Purchase. Procedia - Social and Behavioral Sciences, 81, 212-216

Salisbury, W.D., Pearson, R. A., Pearson, A.W., \& Miller, D. W. (2001). Perceived Security and World Wide Web Purchase Intention. Industrial Management \& Data Systems, 101, 165-176.

Sam, M. F. M., and Tahir, Md. N. H. (2009). Website Quality and Consumer Online Purchase Intention of Air Ticket. International Journal of Basic \& Applied Sciences, 9(10), 20-25.

Samadi, M.,\& Nejadi, A. (2009). A Survey of the Effect of Consumers' Perceived Risk on Purchase Intention in eShopping. Business Intelligence Journal, 2(2), 261-275

Sanchez-Franco, M., \& Roldan, J. (2005). Web Acceptance and Usage Model: A Comparison Between Goal-Directed and Experiential Web Users. Internet Research, 7(3), 21-48.

Selamat, Z., Jaaf, N., \& Ong, B. (2009). Technology Acceptance in Malaysian Banking Industry. European Journal of Economics, Finance and Administrative Sciences, 1(17), 143-155

Shah, H., Aziz, A., Jaffari, A. R., Waris, S., Ejaz, W., Fatima, M. and Sherazi., K. 2012. The Impact of Brands on Consumer Purchase Intentions. Asian Journal of Business Management. 105-110.

Shergill, G.,\& Chen, Z. (2005). Web-based Shopping: Consumers' Attitudes Towards Online Shopping in New Zealand. Journal of Electronic Commerce Research, 6(2), 79-94.

Taylor Nelson Sofres Sdn Bhd. (2000). TNS interactive global e-Commerce report July. Available at:http://worldwide.tnsofres.com/ger/malaysia. htm.

Wakefield, L.,\& Inman, J. (2003). Situational price sensitivity: The role of consumption occasion, social context, and income. Journal of Retailing, 79(4), 199-212.

Yang, L.,\& Mao, M. (2014). Antecedents of Online Group Purchasing Behavior: From Price Leverage and Crowd Effect Perspectives. PACIS. Chengdu, China 